\title{
Fostering Sustainable Cities through Resilience Thinking: The Role of Nature-Based Solutions (NBSs): Lessons Learned from Two Italian Case Studies
}

\author{
Marcelo Enrique Conti *(D), Massimo Battaglia, Mario Calabrese $\mathbb{D}$ and Cristina Simone
}

check for updates

Citation: Conti, M.E.; Battaglia, M.; Calabrese, M.; Simone, C. Fostering Sustainable Cities through Resilience Thinking: The Role of Nature-Based Solutions (NBSs): Lessons Learned from Two Italian Case Studies. Sustainability 2021, 13, 12875. https:/ / doi.org/10.3390/su132212875

Academic Editors: Jan K. Kazak and Marc A. Rosen

Received: 18 May 2021

Accepted: 19 November 2021

Published: 21 November 2021

Publisher's Note: MDPI stays neutral with regard to jurisdictional claims in published maps and institutional affiliations.

Copyright: (C) 2021 by the authors Licensee MDPI, Basel, Switzerland. This article is an open access article distributed under the terms and conditions of the Creative Commons Attribution (CC BY) license (https:/ / creativecommons.org/licenses/by/ $4.0 /)$.
Department of Management, University of Rome, Sapienza, Via del Castro Laurenziano 9, 00161 Rome, Italy; massimo.battaglia@uniroma1.it (M.B.); mario.calabrese@uniroma1.it (M.C.); cristina.simone@uniroma1.it (C.S.)

* Correspondence: marcelo.conti@uniroma1.it; Tel.: +39-0649766298

\begin{abstract}
Adopting an interdisciplinary approach and framing sustainability issues from a resilience perspective, our paper first aimed to highlight nature-based solutions (NBSs) as levers to foster sustainable cities consistent with Agenda 2030-SDG 11 (2015) and the New Urban Agenda (Habitat III, 2016). Second, we empirically analyzed two Italian municipalities that are experimenting with initiatives of sustainable urban management and planning based on NBSs: the Municipality of Lucca in Tuscany and the Municipality of Latina in the Latium Region. These municipalities present institutional and socioeconomic similarities, making them an interesting study setting that allows us to draw significant lessons. We conducted four research steps: (1) theoretical background analysis, including resilience thinking in sustainable urban management. We investigated the role of NBSs in enabling urban resilience according to the last level of resilience, i.e., the transformative level. (2) We studied the contributions of NBSs to sustainable cities and resilience thinking. (3) We analyzed the NBSs' projects of Lucca and Latina, and (4) we proposed an urban managerial tool: the NBSs' curve, which facilitates the estimation of the NBS ecosystem endowment. The results of the NBS initiatives presented in this study have a two-fold value. First, they aim to combine citizens' well-being with ecological and environmental aspects by better managing urban spaces that facilitate interpersonal relationships and resource sharing. Second, they are developed to meet the needs of local groups by serving as a stimulus (Fridays For Future movement) and as enablers (local associations) of managed actions. The lessons learned about the enhancement of sustainable cities through NBSs were thoroughly debated.
\end{abstract}

Keywords: sustainable cities; nature-based solutions (NBSs); resilience; agenda 2030; environmental policy; sustainable urban management

\section{Introduction}

Starting with the first industrial revolution, the exponential rise of cities seems to configure a transition from the "anthropocene" [1] to a new era that the esteemed theoretical physicist and complex systems scholar, Geoffrey West, has called the "urbanocene" [2]. While cities are vibrant laboratories teeming with ideas, innovation, social cooperation, and wealth creation $[3,4]$, exponential urbanization is one of the most significant challenges to global sustainability across issues from climate change and its environmental impacts to crises due to the unavailability of food, water, energy, and essential public services such as health care, urban public transport networks, and public housing.

Considering this perspective, nature-based solutions (NBSs) are a relatively new concept introduced in the late 2000s by the World Bank [5] and the International Union for Conservation of Nature (IUCN) [6] to emphasize the importance of biodiversity conservation for climate change mitigation and adaptation. It was then adopted by the European Commission's [7] “DG Research and Innovation" and defined as follows: 
"Solutions that are inspired and supported by nature, which are cost-effective, simultaneously provide environmental, social and economic benefits and help build resilience. Such solutions bring more, and more diverse, nature and natural features and processes into cities, landscapes and seascapes, through locally adapted, resource-efficient and systemic interventions."

(See the website in the list of references, Section 1.)

Thus, adopting an interdisciplinary approach and framing the sustainability issue from a resilience perspective, our work aimed first to highlight NBSs as levers to foster sustainable cities consistent with Agenda 2030-SDG 11 (targets 11. B, 11. C, and 11.6 2015) and the New Urban Agenda (Habitat III, 2016). Second, through empirical research, we analyzed two Italian municipalities that experienced (and continue to experiment with) urban/sustainable management and planning initiatives based on NBSs: the Municipality of Lucca in Tuscany and the Municipality of Latina in the Latium Region. Lucca is one of the most important, historical, medium-sized cities, and Latina is a medium-sized city located in central Italy (for details, see Section 4.1) born in the 1930s.

According to these two main goals, our study involved four steps. (1) Theoretical background analysis: including resilience thinking in sustainable urban management (Section 2). We investigated the role of NBSs in enabling urban resilience according to the last level of resilience, i.e., the transformative level. As dramatically seen during the COVID19 pandemic, a crucial aspect of development is the ability to bounce forward (rather than bounce back) and to learn from past difficulties. (2) We studied the contributions of NBSs to sustainable cities and resilience thinking (Section 3). (3) We analyzed the NBSs' projects of Lucca and Latina (Section 4). We focused on Lucca and Latina because they represent a case of medium-sized cities adopting NBSs against big cities already widely studied in Italy. However, they are characterized by different historical paths (Lucca is a historic Tuscan town founded in 300 B.C., and Latina was founded relatively recently as it was built in the 1930s). Moreover, in both cases, the promoted initiatives were developed in line with the needs of local groups. They acted as a stimulus (Fridays For Future movement (FFF)) and as enablers (in the case of urban gardening, local associations) of the managed actions, making them not a result of top-down processes but shared actions developed in agreement with representatives of civil society. When evaluating the gap between the "as is" situation with respect to the "to be" situation to improve the urban context from the socio-ecological point of view, it is crucial to assess the current position in terms of the endowment of NBSs and the flow of the needed services. Thus, (4) we proposed an urban managerial tool, the NBSs' curve, which facilitates the evaluation of the NBSs' ecosystem endowment (Section 5). The lessons learned about the enhancement of sustainable cities through NBSs were thoroughly debated.

\section{The Rise of the Urbanocene: The Need to Include Resilience Thinking in Sustainable Urban Management}

Cities are primarily responsible for the constant growth of environmental pressure with the increasing exploitation of natural resources and the consequent impact on the environment and people's health [8-10]. The population explosion in recent years has occurred in parallel with the exponential urbanization of the planet. Half of the world's population and three-quarters of Europe's population live in urban areas. By 2030, urban areas are expected to have $60 \%$ of the global population, and one in three people will live in cities with at least half a million inhabitants. Trends are driven primarily by India, China, and Nigeria, with Delhi becoming the world's most populated metropolis as of 2028 [11].

Facing these challenging trends in a mode that is consistent with the aims of sustainable cities - as called for by the 2030 Agenda-SDG 11 [Making Cities and Human Settlements Inclusive, Safe, Resilient, and Sustainable, in particular, targets 11. B, 11. C, and 11.6], and the (UN's) New Urban Agenda-Habitat III (2016) requires resilience thinking to be included in urban management. 
The word resilience is rooted in the Latin resaltare, which means to rebound, bounce back, and possibly from resilire, which literally means to jump backwards. Referring to complex systems, resilience is the capacity to cope with and react to shocks or persistent structural changes either by resisting such changes (absorptive capacity) or by adopting a degree of flexibility and making minor changes to the system (adaptive capacity) [12]. At the limit at which disturbances are no longer manageable, the system must engineer more considerable changes, which in extreme cases will lead to transforming part of the system, i.e., to creating a fundamentally new system when the extant conditions (e.g., ecological, economic, or social structures) make the existing system untenable (transformative capacity) [13-18]. As a capacity, the question of resilience has found fertile ground in several research fields [19]: engineering and physics [20,21], ecology and biology [22,23], psychology and the social sciences [24,25], disaster management [26], socioecological systems (SESs) [27-29], and managerial and organizational studies [30]. A useful and detailed classification of how the concept of resilience (resilience thinking) has been treated in different disciplines over the past 50 years is in Simone et al. [19].

Resilience thinking has recently gained relevance in urban studies rooted in the complexity perspective [13,14,31-33]. From this perspective, a city is defined as a complex system that emerges through the combination of structural endowments and socioecological and sociotechnical components that dynamically interact, giving rise to recursive and often unpredictable feedback loops $[19,34]$.

\section{Sustainable Cities and Resilience: The Contribution of NBSs}

Including resilience thinking in urban management enables a deeper understanding of urban issues for three main reasons.

First, resilience thinking highlights the need to consider both the structural and a systemic dimension of a city context: Urban management leveraging resilience should take into account both infrastructure planning and the emerging interactions among the population, i.e., the relationships activated among individuals, organizations, institutions, and the environment that evolve dynamically and recursively within the city itself, sometimes with nonlinear feedback. This system perspective helps us understand how shocks affect the interdependent elements of the system, how they spread within the system, and, on this basis, how to intervene. On the other hand, the ambiguous role played by technology in enabling resilience should be considered: Sometimes technology acts as a resilience amplifier; sometimes it is a resilience blocker; sometimes it provokes an unwanted deviation from codified rules [35].

Second, resilience thinking considers the city's capacity to respond to disturbances and sudden changes across space and time, even transforming itself to avoid unsustainable trajectories. This second aspect is essential as resilience can reveal a "dark side": In its absorptive mode, resilience is intrinsically conservative and could slow well-being development and perpetuate inequalities, especially in unjust and dysfunctional urban contexts [31-33,36-43].

Third, resilience thinking seeks to exploit shocks as windows of opportunity and thereby translates the negative narrative of a "stormy future" into a positive narrative [17]: The crucial need for such capacity is demonstrated in the ongoing COVID-19 pandemic.

For all the abovementioned reasons, including resilient thinking in urban management incorporates the dynamic interplay of persistence, adaptability, and transformability across multiple city context dimensions (structural and systemic) and at multiple scales [15]. Beyond the definition of resilience provided in the first part of this section, urban resilience cannot be defined only as a city's capacity to adapt to changes either by absorbing sudden disturbances (absorption) or by managing to maintain or restore initial functions without limiting future adaptability (adaptation). The definition of resilience also involves intense alterations and disturbances such as the capacity to design and undertake broader and deeper changes that can actually ensure survival and sustainability through transformation (transformability). In other words, urban resilience configures not only the capacity to 
"bounce back", a capacity that seems to be more about robustness (from the Latin robustus, in turn derived from robur that means "strength") to change [44] but also the capacity to "bounce forward" by learning from past difficulties and being able to positively transform in response to shocks that are seen as opportunities rather than threats [19].

Overall, NBSs provide benefits on both the biodiversity and human well-being fronts [6] and range from solutions such as urban agriculture for local food production, green spaces for climate change adaptation and mitigation, the regeneration of brownfields through afforestation or park creation, rain gardens for stormwater regulation, green and blue spaces for the promotion of human health and well-being and the conservation and enhancement of urban biodiversity, the use of permeable surfaces and vegetation in urban environments, and the promotion of economic opportunities for green enterprises and the creation of "green jobs" [45]. As living solutions inspired by and based on nature, NBSs are thus aimed at fostering biodiversity and supporting a wide range of ecosystem services [46,47]. They constitute a systemic, multifunctional, and cost-effective approach that is highly consistent with the 2030 Agenda-SDG 11 and the New Urban Agenda-Habitat III concerning the challenges they aim to address with respect to the risks of the unsustainability of a highly urbanized society. Thus, NBSs are considered an effective means of integrating natural ecosystems into sustainable development at the urban level. Due to their prerogatives, NBSs are increasingly being considered to promote not only bounceback resilience (i.e., absorbing or adapting resilience) but also to provide cities with the capacity for bounce-forward resilience (transformative resilience).

Pioneer cities for NBSs are Dortmund (Germany), Turin and Milan (Italy), Zagreb (Croatia), and Ningbo (China). These cities have long hosted living labs in postindustrial districts where nature-based solutions are developed, tested, and implemented (see list of websites, Section 3). The European Union has adopted the European NBSs' Agenda aiming at four main goals: enhancing sustainable urbanization, restoring degraded ecosystems, developing climate change adaptation and mitigation, and improving risk management and resilience.

\subsection{NBSs: An Umbrella Term?}

The term NBS encompasses many interrelated concepts that have found wide usage in international and local policies. The European Commission has identified more than 300 nature-based solutions ranging from the protection and expansion of forested areas to the promotion of carbon sinks $[48,49]$ to the construction of green roofs. NBSs can be considered an "umbrella term" as they encompass a wide variety of approaches and solutions [50-56] that innovatively and synergistically combine existing concepts such as green infrastructures (GIs) and blue infrastructures (BIs), ecological engineering (EE), ecosystem services (ESs), and ecosystem-based adaptation (EbA).

The first and second concepts that fall under NBSs are GIs and BIs. GIs consist mainly of well-functioning biophysical systems: sustainable oyster reefs, coastal salt marshes, mangroves, coral reefs, seagrasses, sandy beaches, dunes in the coastal environment, forest parks, and street trees, to which some management and restoration systems can be applied [57-60]. BIs include all water bodies such as ponds, wetlands, rivers, lakes, streams, estuaries, seas, and oceans. Water and land are strictly connected in multiple ways including riparian areas, beaches, wetlands, and more. The combination of green and blue infrastructures is gaining attention in research and practice to combat climate change and reduce disaster risk [61]. Recently, concerning the concept of urban ecological infrastructure, Childers et al. [62] argued that wetlands have ecological structures and functions that can be either terrestrial or aquatic or both or neither.

Ecological Engineering is committed to developing technology that connects society with the environment $[63,64]$. EE has been applied in coastal adaptation approaches to managing the uncertain dynamic forces of coastal environments using marshes, mangroves, and oyster reefs [65]. 
Ecosystem services, the fourth concept, has been defined as "benefits that people gain from ecosystems" [66]. Nature is the basis for producing food, clean water, and fresh air; natural elements, such as trees and other vegetation, act as filters for air pollution and can reduce, for instance, the risk of flooding from stream retention. Of critical importance is that nature influences human beings, for example, by providing healthy environments for educational purposes, offering inspiration, and promoting creativity $[67,68]$. ESs can play a crucial role in reconnecting cities to the biosphere and reducing the ecological footprint and ecological debt of cities while improving the resilience, health, and quality of life of their inhabitants $[69,70]$.

The last concept of ecosystem-based adaptation is defined as "the use of biodiversity and ecosystem services as part of a comprehensive adaptation strategy to help people adapt to the adverse effects of climate change" [71]. Its main objective involves the provision of services for adaptation to climate change through the management, conservation, and restoration of existing ecosystems [72].

It should be noted that the first three terms (i.e., GIs, BIs, and EE) refer to the NBSs intended for cities' endowment (i.e., the nature-based ecosystem and its elements); the fourth and fifth terms (ESS and EbA) pinpoint the services' flow generated by a specific NB endowment and constitute a useful perspective when assessing the benefits to be gained from nature. The distinction between endowment and service-which is not adequately highlighted in the extant literature-is not neutral in urban management. When assessing the gap between the "as is" situation and the "to be" situation to improve the urban context, it is crucial to assess the current position in terms of both the NB endowment and the flow of the needed services. In fact, from a structural point of view, GIs, BIs, and EE are overlapping solutions; conversely, they should not be considered alternatives but complementary solutions. Each has its characteristics, strengths, and weaknesses. There is an intense debate in the recent literature [56,73-75]. For this reason, careful evaluations are necessary for their joint action depending on the type of desired goals in the specific urban context [68]. To this end, assessing the services' flow potentially triggered by different endowments is relevant in the selection of the most satisfactory (even if not the best) solution among a wide set of alternatives, considering the specific urban context and the needs of heterogeneous (sometimes conflictual) stakeholders.

Strictly related to the previous taxonomy, a second NBS taxonomy has been proposed: It involves the required intervention and the area in which NBSs are applied. This second taxonomy distinguishes three types of NBSs [6,76].

Type 1: solutions that involve the use of existing ecosystems, both protected and natural (e.g., increasing the amount of fish in an intact wetland to improve food quality);

Type 2: solutions based on the development of sustainable management protocols and procedures for ecosystem restoration (e.g., restoring biodiversity); and

Type 3: solutions involving the creation of new ecosystems. Examples of Type 3 are represented by the creation of walls, roofs, and green walls that integrate existing structures and that are, therefore, artificial ecosystems [76]. This type involves the management of ecosystems through a very invasive approach with a very high level of engineering or the creation of ecosystems from scratch using vegetation to mitigate the urban heat island effect (UHI), noise, or air pollution.

Even if the boundaries between these three types are not clearly and conspicuously defined, a greater thrust of human intervention and effort characterizes Types 2 and 3 . As discussed in Sections 4 and 5, the two taxonomies can facilitate the planning and assessment of an NBS project's cost-benefit analysis [48].

\subsection{NBSs as Levers for Sustainable Cities}

According to a resilient perspective in urban management, NBSs are effective levers in facing the challenging problem [77] of fostering sustainable cities. Due to their multifaceted features, NBSs ensure a comprehensive and systemic set of community services to promote a city's health and well-being according to self-reinforcing virtuous feedback loops. Here, 
the role of NBSs as levers for sustainable cities is illustrated by a systemic framework rooted in the "materially closed Earth system" model of Costanza and Folke [78] and based on four main elements (Figure 1).

Virtuous feedback loops: increasing ask for NBSs

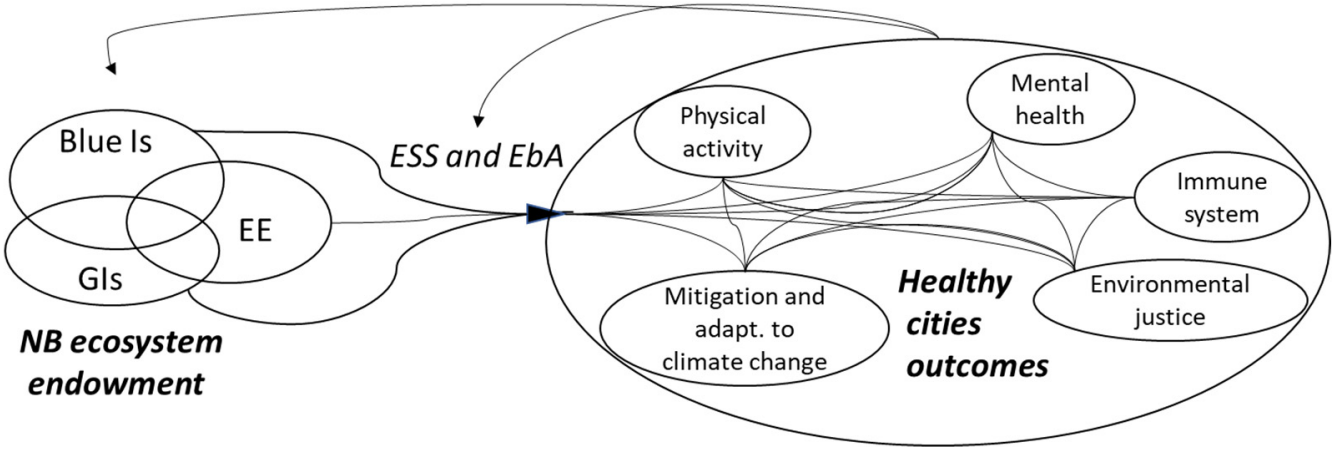

Figure 1. NBSs as sustainable cities' levers: a self-reinforcing cycle. Source: our elaboration. [BIs: Blue Infrastructures; GIs: Green Infrastructures; EE: Ecological Engineering; ESS: Ecosystem Services; EbA: Ecosystem-based Adaptation].

The nature-based (NB) endowment (the asset) provides a flow of ecosystem services ensuring people's well-being (outcomes, i.e., target variables), that in turn stimulate the demand for new NB endowment and NBS management (positive, i.e., self-reinforcing, feedback loops).

In particular, by focusing on people's well-being, the target variable, it is possible to identify five intertwined types of outcomes enabled by NBSs $[79,80]$ : 1 . physical activity, 2. mental health, 3. physical immunity, 4 . environmental justice, and 5. mitigation of and adaptation to climate change.

\subsubsection{Physical Activity}

Nature-based solutions, such as green parks, encourage individuals to regularly access such environments, which generates multiple benefits [81]. Recreational walking, increased physical activity, and reduced sedentary time have been associated with access to and the use of green space by adults, children, and seniors [82]. The possibility of using parks, water sources in cities, or green buildings allows people to benefit from certain services such as noise reduction and psychophysical well-being [83]. Many epidemiological studies [84] have demonstrated various positive health effects of urban green spaces including reduced cardiovascular morbidity and mortality, improved pregnancy outcomes, and reduced obesity and diabetes.

\subsubsection{Mental Health}

Exposure to nature-based solutions supports mental health: "[...] a state in which a person is more satisfied, can make sense of their surroundings, feel in control, i.e., able to cope with daily needs and have a purpose in life" [85].

There are several ways to promote mental health through exposure to the natural environment. These include nature's ability to reduce stress, create positive affective states, and improve cognitive functioning $[80,86]$. Another critical factor is the lack of affectivity in interhuman relationships, which is the leading cause of depression $[87,88]$. Finally, NBSs can alter the affective state in children $[89,90]$ with positive mental health implications. It has been found that there is less bullying in children's play spaces with a highly interactive and engaging natural environment [91].

\subsubsection{Physical Immunity}

NBSs can improve the functioning of the human immune system. Li et al. [92] demonstrated associations between forest visits and beneficial immune responses including the 
expression of anticancer proteins. In addition, living in residential areas with more street trees is associated with a lower asthma prevalence [93]. Natural biodiverse environments may play an immunoregulatory role [94]. Other studies have shown that increased biodiversity in home environments is linked to a reduced risk of allergies [95,96].

NBSs can improve the functioning of the human immune system. Li et al. [92] demonstrated associations between forest visits and beneficial immune responses including the expression of anticancer proteins. In addition, living in residential areas with more street trees is associated with a lower asthma prevalence [93]. Natural biodiverse environments may play an immunoregulatory role [94]. Other studies have shown that increased biodiversity in home environments is linked to a reduced risk of allergies $[95,96]$.

\subsubsection{Environmental Justice}

Creating and managing NB endowments are cost-effective initiatives that can improve public health and address health inequities. Public urban green space has been shown to facilitate social networking and promote social inclusion, although the most vulnerable age groups, children and the elderly, have difficulty [97-99]. Urban green public places are often located in the center of cities and rarely in peripheral areas, where the population's poorest segments live. Therefore, inequality of access to urban green space has become an environmental justice issue [100-102]. Urban planners use threshold values to coordinate urban green spaces in cities with the aim of safeguarding their amount. This ensures that all city residents have a minimum amount of urban green space in their vicinity [103]. In fact, as Allen and Balfour [104] stated, reducing social and economic disparities in the availability of urban green space can help reduce health inequalities related to income, minority status, disability, and other social, economic, and demographic factors.

\subsubsection{Mitigation and Adaptation to Climate Change}

Heat waves, intensified by the urban heat island effect (UHI), are often linked to areas with little or no green space in cities and often cause premature death and disease $[105,106]$. Air pollution from traffic and industrial sources has increased with increasing urbanization [107]. However, NBSs make it possible to temporarily adopt solutions to mitigate deleterious effects, for example, by reducing the rate of deforestation, promoting the recovery of forests and ecosystems as natural tools that can absorb carbon dioxide, and mitigating air pollution.

\section{Italian Experiences: NBS Projects in the Towns of Lucca and Latina}

Despite the increasing importance given to NBSs at the national and international levels, e.g., in many North American and North European public administrations, studies implementing NBSs are still limited to local areas, and NBSs have not been integrated within a systemic vision. The NBS projects already internationally recognized as successful initiatives in Italy include the urban infrastructure of Bosco Verticale (Vertical Forest) in Milan [108-110] and the Mirafiori Sud Living Lab, which is part of the ProGireg project, a "productive green infrastructure for post-industrial urban regeneration" in a former FIAT automotive production center in Turin (see websites' list, Section 4). In this paper, two research experiences involving two medium-sized Italian cities are reported to represent understudied settings.

\subsection{Method}

The case was designed following an exploratory, qualitative analysis based on two experiences, whose initiatives provide insights for theoretical and urban managementrelated future actions [111,112]. A case study enables researchers to collect real data from one or more organizations to draw up a theory or further explore a pre-existing theory on a topic that has not yet been fully explored. The research is based on collecting data related to two Italian municipalities that experienced (and continue to experiment with) urban 
management and planning initiatives based on NBS: the Municipality of Lucca, in Tuscany, and the Municipality of Latina, in the Latium Region.

Lucca was founded by the Etruscans in 300 B.C., and it is one of the most important, historical, medium-sized cities in Tuscany. It is located in central Italy, has approximately 100,000 inhabitants, an extension of $190 \mathrm{~km}^{2}\left(73.3 \mathrm{mi}^{2}\right)$, and a density of approximately 480 inhabitants per $\mathrm{km}^{2}$. Latina is a medium-sized city located in central Italy. It has approximately 120,000 inhabitants, $287 \mathrm{~km}^{2}$, and a density of 456 inhabitants per $\mathrm{km}^{2}$. It was founded in the 1930s and is one of Italy's youngest cities. Although they are characterized by very different historical paths, these municipalities present institutional and socio-economic similarities, which make them an interesting study setting. Both cities are the capital of their province. They are centers of activities and services (such as schools, healthcare, and public administration) that are provided to many citizens who live near the city center as well as in the neighboring areas. Both cities have a good infrastructural endowment (train station, airports less than $50 \mathrm{~km}$ away, important roads) and a good connection with larger cities (such as Rome and Florence) without suffering dependence on them. There are branches of important national universities in both cities and a relevant tradition of associations that characterize local social and relational capital. From an industrial point of view, both cities are at the center of important industrial clusters characterized by innovative and medium-sized enterprises: the Latina pharmaceutical cluster (with more than 5000 employees) and the Lucca paper industrial district (with approximately 6500 employees). Finally, both cities are close to areas of great naturalistic value, with parks and naturally protected areas, which provide many amenities. Because of these features, both cases represent important teaching examples for other Italian and foreign similar contexts as well as a set of researched yet understudied medium-sized cities. Other urban contexts (in particular in Italy, where they are widely diffused) can take inspiration from these cases, which highlight that the adoption of a participatory NBS process can represent a sustainability-based process of urban improvement.

The initiatives carried out in the field of the urban management of NBSs in these two cities were the object of this research. In both municipalities, technical and programming documents were collected and extensively analyzed. Documents and experiences were derived from different departments: urban planning, social affairs, and environmental protection. The process of data collection was developed in three steps, as synthesized in Table 1. Documents collected are listed in Table 2. The research lasted 8 months (from May 2000 to January 2021).

The analysis of evidence that emerged in the third phase was based on the comparison method $[113,114]$. With this method, the data (as listed in Tables 1 and 2) were analyzed simultaneously, and the common properties were identified [115] based on the different types of NBSs. These categories were used as a reference, and the initiatives identified in the two municipalities were deepened with respect to each of them. This collection of systematized information was used to develop a model outlining how policy makers can manage NBSs at the urban level. In this way, the reasoning started from some statements to obtain proof and explain the two cases analyzed. The deductive process, in fact, connected the premises with the conclusions. The work used the deduction to verify the validity of the premises and, subsequently, through the cases of the two cities, the validity of the hypotheses formulated was demonstrated.

The following sections report the results of this analytical process in both municipalities and the model derived. 
Table 1. Data collection.

\begin{tabular}{|c|c|c|c|}
\hline Step of Research & Period (Months) & Types of Data Collected & Methods of Data Collection/Analysis \\
\hline 1 st & May-August & $\begin{array}{l}\text { Preliminary selection of main } \\
\text { initiatives related to NBSs } \\
\text { promoted and carried out in } \\
\text { each municipality, based on } \\
\text { what developed locally }\end{array}$ & $\begin{array}{l}\text { Interviews * with both political and technical } \\
\text { representatives of both municipalities. A flexible } \\
\text { open interview protocol was used. } \\
\text { Lucca: Three politicians and seven technical } \\
\text { representatives of the municipality; } \\
\text { representatives of the local FFF group. } \\
\text { Latina: Two politicians, three technical } \\
\text { representatives, five entrepreneurs of the } \\
\text { horticultural sector }\end{array}$ \\
\hline 2nd & September-December & $\begin{array}{l}\text { Details of initiatives carried } \\
\text { out in each municipality, the } \\
\text { use of official planning and } \\
\text { managerial documents } \\
\text { drafted and approved }\end{array}$ & $\begin{array}{l}\text { Collection of documents related to the initiatives } \\
\text { described during interviews and their } \\
\text { classification based on their relevance in terms of } \\
\text { connection to NBSs (see Table 2). }\end{array}$ \\
\hline $3 \mathrm{rd}$ & December-January & $\begin{array}{l}\text { Relevant documents collected } \\
\text { and selected in the } \\
\text { second step }\end{array}$ & $\begin{array}{l}\text { Analysis of the main evidence emerged, } \\
\text { connecting them to the elements characterizing } \\
\text { the NBSs listed previously (comparison method) }\end{array}$ \\
\hline
\end{tabular}

\footnotetext{
* Because of the COVID pandemic, all interviews were carried out online. Interviews were not recorded, but extensive notes were collected.
}

Table 2. Documents collected during the research.

\begin{tabular}{cc}
\hline Dunicipality & Documents \\
\hline Lucca & Local Sustainability Action Plan \\
Urban Green Plan \\
3-year public works plan \\
$\mathrm{CO}_{2}$-equivalent measurement cards \\
Minutes of meetings with representatives of local Fridays For Future \\
Climate emergency declaration approved by the local town council \\
Agreements signed with local association for urban gardening projects \\
UPPER main project \\
UPPER work packages description (n. 8 WPs) \\
UPPER Gantt \\
UPPER budget \\
Latina \\
Latina's floor plans
\end{tabular}

\subsection{The NBS Initiatives Carried Out in Lucca}

The projects developed by the Lucca Municipality began in 2018 following a series of requests and pressures exerted by a group of local young protestors of the FFF movement (see website list, Section 4.2; [116,117]). In particular, the local FFF movement, inspired by the Swedish student Greta Thunberg, began to strike in front of the town hall, requesting Lucca's local government to take climate action and demanding a strong commitment to adopting a strategy to improve territorial sustainability-related performance [118]. Under local FFF movement pressure, the local administration (and, in particular, the local environmental city councilor) developed a 5-year program (the "Local Sustainability Action Plan"), which involved different municipality departments and articulated projects containing sustainability-related goal actions, deadlines, and performance indicators. Regarding the measurement instrument (that is, the performance indicators), a system based on the estimation of the $\mathrm{CO}_{2}$-equivalent savings for each project was developed in accordance with WRI and WBCSD [119] guidelines (see website list). Decisions about these projects and the need to monitor the effectiveness in terms of air pollution reduction by means of an internationally recognized method were shared by the representatives of the municipal office for environmental protection in collaboration with the group of local representatives of the FFF movement. The dialogue was continuous and organized through meetings in 
which the proposals of the municipality were shared with local political and technical representatives. The needs and expectations of the FFF movement representatives were taken into consideration by the local government representatives. Attention to the measurement of results (and the adoption of an official method of quantifying $\mathrm{CO}_{2}$-eq reduction for the evaluation of benefits associated with the developed projects) was one of the main requests of local FFF representatives as an opportunity to increase the credibility of planned actions.

Concretely, the selected projects involved both the energy redevelopment of buildings and actions to regulate traffic flows as well as interventions focused on NBSs. The project's aim was to expand and redevelop urban green spaces (see websites' list in Section 4.2). These actions provide for the creation of four new green areas and the conversion of other abandoned urban parks. The idea behind this activity is that of the "10-min neighborhood", which describes neighborhoods where citizens can reach and take advantage of parks, gardens, or green areas in 10 min travelling on foot or by bike. A total of 11 neighborhoods were affected, nine of which were "outside the city walls" in peripheral areas. The interventions (which are still ongoing) aim to plant more than 5000 new trees in 3 years (from 2020 to 2023), with a preference for endemic tree species with a greater carbon sequestration capacity. This project aims to produce positive mitigation effects, especially at the microclimatic level, and to recover areas on the outskirts and redevelop neighborhoods that are now in a state of significant abandonment. The design of these integrated green areas has been developed to reduce citizens' exposure to risk factors arising from polluting substances in the air and to increase their enjoyability due to ecological corridors (which provide benefits to citizens' mental and physical health). The absorption of fine dust by trees is a useful tool for reducing the negative impact of air emissions in the city of Lucca, which the Regional Authority classifies as a municipality subject to remediation actions for its excessive number of PM10 and NOx overruns. The carbon sequestration for 3 years is estimated at approximately 1600 tons of $\mathrm{CO}_{2}$ equivalent, with approximately 500 tons/year benefits. Finally, urban green areas will contribute to the creation of urban habitats for animals and new plant species, the reduction of the urban temperature, and the mitigation of noise. These effects are a direct contribution to the targets of SDG 11 and, in particular, to targets aimed at reducing the adverse per capita environmental impact of cities and creating safe, inclusive, and accessible green public spaces (i.e., 11.3, 11. B, 11C, 11.6). Another project based on natural solutions involves the recovery and restoration of old natural canals in the city center and city fountains. This intervention (whose deadline is, again, 2023) has the dual objective of urban restoration and redevelopment of the city center and facilitating cooling conditions in summer (with benefits for both citizens and tourists). The carbon sequestration associated with this project is approximately 100 tons of $\mathrm{CO}_{2}$ equivalent in 7 years (approximately 15 tons/year), from 2023 to 2030, derived by the estimation of the positive effect associated with the reduction of urban temperature and the mitigation of the so-called "heat island effect."

In addition to the interventions mentioned above, in 2017, the municipality activated a project to encourage urban gardening $[120,121]$ in the peripheral areas of Lucca. The project has been integrated into the abovementioned 5-year program. It has been developed with different objectives. They first favor the green redevelopment of the city and an increase in the availability of local green spaces for climate change adaptation and mitigation. Moreover, the project aims to encourage socialization among citizens, promote educational and leisure initiatives, stimulate intergenerational exchange, promote environmental sensitivity and healthy lifestyles, and revitalize and recover the urban fabric with experimentation in the shared management of common goods. The goal is to create a new model of social and ecological development in a system in which services, shared spaces, and aggregation points are committed to improving the well-being and health of citizens as well as experimenting with a new mode of spatial planning based on the principles of social justice [122-124]. The project involves the recovery of approximately 280 hectares of urban area. Two associations of local citizens were involved as partners ("Comitato Popolare Piazza San Francesco" and "Fattoria Urbana Riva degli Albogatti") to 
share the criteria for the allocation of portions of land to citizens and the materials required for urban farming.

A two-fold value characterizes the initiatives mentioned above. First, they aim to combine citizens' well-being (mental and physical health) with ecological and environmental aspects by better managing urban spaces that facilitate interpersonal relationships and resource sharing. New ecological corridors, new urban parks, and the sharing of soil for cultivation are all facets of a unique project in which environmental and social qualities are integrated into the planning and management of urban areas. Second, the initiatives promoted were developed in line with the needs of local groups. They are designed to serve as stimuli (FFF movement) and as enablers (local associations, in the case of urban gardening) of the managed actions, not as a result of top-down processes but as the outcome of shared actions developed in agreement with representatives of civil society.

\subsection{The NBS Initiatives Carried Out in Latina: The UPPER Project}

In recent years, Latina's city has experienced intensive urban growth, leading the municipality to expand quickly. However, this constant increase due to urbanization has led to the improper use of natural resources. This has led to a reduction in the number of green places per number of inhabitants, accompanied by poor park maintenance and safety, which induces citizens not to frequent them. In addition, other problems of a social and economic nature subsequently arose such as a high percentage of unemployed youth, approximately $45 \%$, and the illegal exploitation of immigration carried out through criminal activities that revolve around the city of Latina and racial discrimination suffered by ethnic minorities. Moreover, another issue is the lack of public economic resources that are useful for managing, improving, and ensuring both green and blue ecosystems. In 2018, the municipality of Latina decided to face the increasing problems related to urbanization growth by adopting NBSs. It joined one of the UIA (Urban Innovative Actions) projects promoted by the European Union to fund the implementation of NBSs in Latina. The project was called UPPER, "Urban productive parks for development of NBS-related technologies and services" (see website list, Section 4.3). The UPPER project was officially launched on 1 September 2019, and it involves a synergistic network of partners: the Municipality of Latina (the lead partner) and a multidisciplinary group of nine delivery partners that cover national and regional environmental institutions (the National Park Authority and the regional public-private Foundation Caetani), the NGO sector (two social enterprises and one no-profit association), the research institution sector (Cersites Sapienza University of Rome), the private for-profit sector (one multinational company), one national cities' association (Tecla), and one international studio that specializes in participatory urban planning (Tesserae). The project was also supported by a wider group of stakeholders composed of three NGOs, two networks of local associations, two neighborhood associations, and one business incubator.

Based on SDG 11-Make cities and human settlements inclusive, safe, resilient and sustainable, target 11.3 ("By 2030, enhance inclusive and sustainable urbanization and capacity for participatory, integrated and sustainable human settlement planning and management in all countries"), UPPER experiments with the innovative use of urban green areas and created the first urban productive parks. These parks are intended for the research, development, and self-production of NBSs to address environmental, social, economic, and governance challenges (e.g., self-production of NBS is intended as the use of native species for environmental remediation). UPPER proposes a broader approach to the NBS concept including, on the one hand, vegetation and GIs and, on the other hand, innovative outdoor services and activities (social care, inclusive jobs, training, education, sports, creativity, and entertainment).

The proposal foresees the regeneration of three abandoned urban areas that will be restored to become productive parks, plus eight demonstration sites for the development and testing of NBSs' self-production (plants for water and soil phytoremediation, native trees to fight the "heat island" effect and pollution, filtering and reinforcing plants for 
small engineering interventions on canal banks and coastal dunes). UPPER also piloted an initiative based on public and private owner participation (the Green Areas Bank) to match supply and demand for self-produced NBSs. Finally, the project supports social enterprises and start-ups to promote green jobs and ensure the market enhancement of productive parks (see website list).

As mentioned above, one of the original and valuable NBSs underpinning the UPPER project is the idea of urban productive parks. Such parks are designed to transform misused and abandoned urban and peri-urban areas into areas devoted to research, technological development, and the self-production of advanced NBSs and innovative nature-based services to tackle the town's main environmental, health, and socioeconomic challenges. The idea of urban productive parks involves developing green spaces that are accessible to citizens and available for cultural and social activities that also integrate production functions. They provide for the activation of entrepreneurial activities and the creation of green jobs to produce goods and services related to NBSs including spaces for educational services, social integration, health, and sports. These productive parks will be codesigned and comanaged by project partners (Cersites Sapienza University of Rome, Innovation Europe, Engie ServiziSpA, Fondazione Caetani) with citizens and stakeholders. At the same time, a public-private system will be designed for future management and sustainability. Moreover, the three urban productive parks are quite heterogeneous and thereby contribute to the town's biodiversity (see website list for the Urban Productive Parks):

- Urban Productive Park 1-Campo Boario. The site is dedicated to the implementation of a nursery for functional plants; it will host a training center and workplace for the job inclusion program in the project and an assistance and consultancy center for start-ups. It will be a safe, accessible, and recovered public green area equipped with a soccer field and play areas. The park will host a municipal nursery that is open to the public and a guidance and support center for new businesses in the green sector (NBS Business Information Point). The types of trees applied will be deciduous and evergreen trees.

- Urban Productive Park 2-The Market Area. It will be a multifunctional space dedicated to psychophysical well-being and sociality. The nature-based solutions tested in this park will include recreational, sports, social, and educational activities organized in collaboration with schools and social actors in the area.

- Urban Productive Park 3-The Green Outfall. The area is suited to an intervention of renaturalization and experimentation with vegetation cultivation with phytoremediation characteristics. Moreover, a demonstration site for new plant species with a filter function against polluting substances from the road will be built.

UPPER represents a solution that has never been implemented before and can add significant value for the following reasons:

a. It is the first solution that transforms a problem such as the maintenance and development of GIs and BIs into a structured program for the labor inclusion of vulnerable citizens. Until now, this problem has been addressed only marginally and limited to the development of urban farms (H2020 Edicitnet and Progireg projects, Green Surge project and Nomadic Garden in Berlin, food production in Dresden, Green Surge project in Edinburgh, Heempark and Modeltuin project in Genk, UIA Open Agri project and South Agricultural Park in Milan). The UPPER project will differ from these existing solutions since it will be the first European example of a productive park not dedicated to the production of primary goods (agri-food), but it concerns the production of NBSs and innovative services based on nature.

b. UPPER will also focus on the financial sustainability and long-term maintenance plans of NBSs and related GIs and BIs, which is a fundamental issue for small- and mediumsized cities with limited economic resources. Indeed, while most projects focus on the technological development of NBSs as an external (and expensive) expertise and resource for municipalities (e.g., the London plan and the FP7 TURAS project for green roofs and walls of London, rainwater storage and ecosystems related to a wetlands' 
recovery plan in Rotterdam, the vertical garden plan for the H2020 Progireg project and related cities, the H2020 Clever City project), the UPPER solution focuses on selfproduction and on the self-maintenance of NBSs in all municipal productive parks, built on "People-Public-Private" (PPPP) Partnerships, new governance and financial systems and public incentives to ensure long-term sustainability and expansion of the solutions for sustainable cities.

c. There are some examples of projects that transform landscape management into an opportunity to stimulate the green economy (e.g., the UIA Ufil project in Cuenca). Nevertheless, the UPPER project is not limited only to the development of future enterprises and green business models; it is designed to transform the city itself into a market for NBSs within the lifetime of the project, testing the production and delivery of NBSs to the city, its inhabitants, and other public and private stakeholders as a new business model.

\section{Discussion. Enhancing Sustainable Cities through NBSs: A Resilience-Based Framework from the Italian Lessons Learned}

The two cases refer to two medium-sized cities that have developed plans to foster NBSs to improve the living conditions of citizens and react to the pressures of climate change at the urban level. These two cases show some common traits worthy of attention.

First, it is important to stress the participatory nature of these initiatives and their ability to catalyze the attention of a multitude of local stakeholders while representing heterogeneous interests. From this perspective, NBSs must be managed through governance that integrates different and sometimes conflictual economic interests and actively involves a large number of stakeholders.

Stakeholders can be of stimulus to the planning and management processes (as happened in Lucca for the FFF movement, or in Latina with the NGOs and the Regional Foundation) or they may be actively involved in these processes as partners or enablers (such as the associations involved in urban gardening in Lucca or the People-Public-Private Partnerships (PPPP) created in Latina as part of the UPPER project). In addition, in both cases, relationships were activated with the representatives of other local entrepreneurial and social activities (commercial operators, tour operators, associations, and committees) who were interested in the relationship between these processes and their own interests. In this way, a new model of extended governance is developed in which NBSs act as a catalyst role due to their multiple implications: the aesthetic aspects of the redevelopment of the urban heritage and the consequent importance for the recreational activities of citizens, enhancement of urban capital in terms of local businesses (for the tourism and accommodation sector, for commerce, for local crafts), and the possibility of generating local, new relationships among citizens concerning the use of common spaces that are in a state of neglect. All these elements have an intergenerational and multifunctional character and they allow a significant improvement of urban areas in the sense of sustainable contexts. Indeed, the livability of new urban spaces stimulates generational integration on the one hand. On the other hand, it qualifies the territory by setting the conditions for greater attractiveness that generates local new businesses.

Second, the analyzed case studies demonstrate that NBSs give value to the local dimension of sustainability and generate the population's well-being and health.

Third, the two cases show that the resilient quality of the urban context can be conceived as a function of decision-making processes. The decision-making processes adopted by local authorities can, therefore, influence the resilience of urban contexts, and NBSs emerge as a useful tool to promote sustainability-oriented governance. This, in turn, stresses the urgency of including resilience thinking at the center of urban management to achieve the objectives of Agenda 2030-SDG 11 and the New Urban Agenda (Habitat III). Both Lucca's and Latina's NBSs' projects are rooted in resilience thinking and demonstrate that NBSs facilitate valuable adaptive and transformative experiments at small scales, allow cross-learning and new initiatives to emerge, and trigger a virtuous social mobilization. 
Figure 2a,b proposes an integrated framework of the variables discussed in Section 2, Section 3.1 and Section 3.2-level of resilience capacity, NB endowment, and types of intervention-which describe the ongoing transformation process of Lucca and Latina promoted by NBS projects, moving from the "as is" situation (i.e., before starting the project, points " $\mathrm{t}_{0}$ ") to the "to be" situation (i.e., expected at the end of the project, points " $\mathrm{t}_{1}$ "). (For Latina, for reasons of space, Figure $2 \mathrm{~b}$ refers only to the three productive parks.) The shift is intended to improve all three classes of ecosystem endowment, leading both cities to enhance the local NBSs' offer curve. This model links the NB endowment (on the horizontal axis) with the types of intervention (on the left vertical axis) with the levels of resilience capacity associated with transformation processes (on the right vertical axis). It can represent a useful support tool in the decision-making processes of the administrations involved in adopting NBSs for urban redevelopment and regeneration, providing ex ante a hypothesis of path development.

A

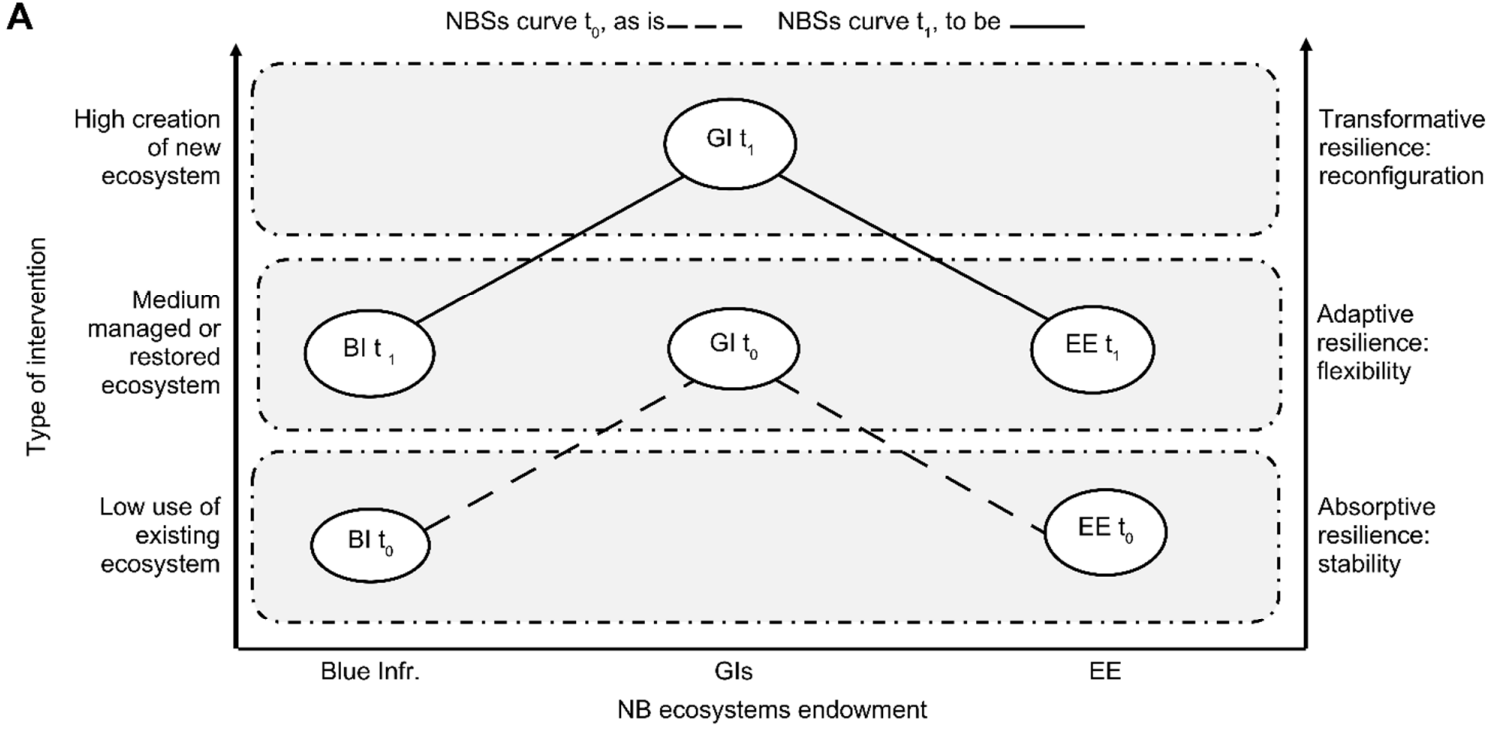

B

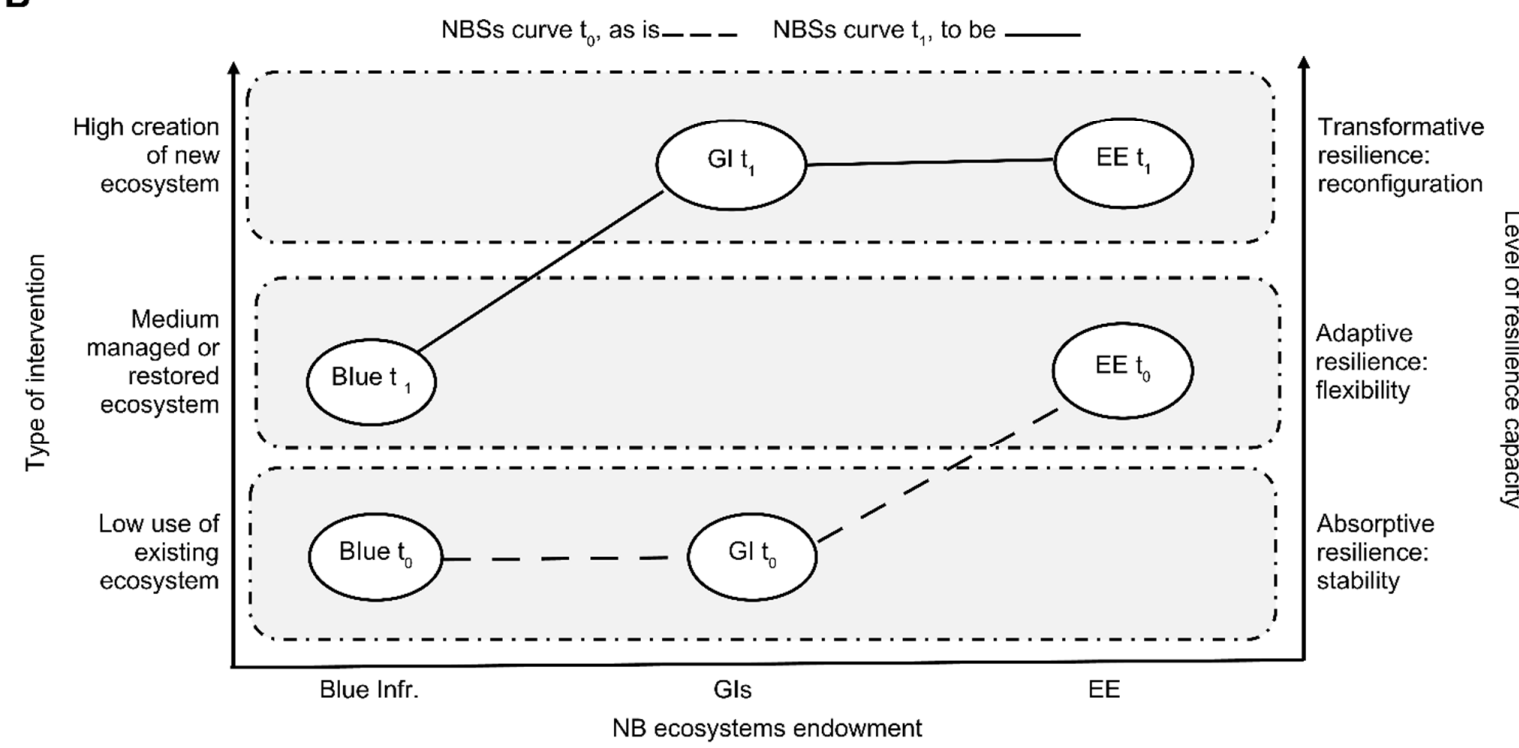

Figure 2. (A) Leveraging NBSs for sustainable cities: the Lucca NBSs' curve; source: our elaboration. (B) Leveraging NBSs for sustainable cities: the Latina NBSs' curve; source: our elaboration. 
The sustainable expectations expressed by local interest groups represent the drivers of interventions to be adopted at the local level and allow for the identification of "which" NBSs can be selected and which opportunities can be designed for the territory. Then, in perspective, the local authority defines the achievable improvement targets and draws (in collaboration with other local subjects) the paths through which the NBSs may modify the current levels of the system's resilience (it represents the "how"). Finally, the adoption of specific indicators that are capable of designing the trend associated with a specific ecosystem configuration (i.e., $\mathrm{CO}_{2}$-equivalent savings adopted in the case of Lucca or square meters of unused space restored, as proposed in the ongoing project in Latina) allows the provision of measures of the improvements obtained and supports subsequent decision-making processes (it represents the "how much").

The resulting systemic model allows the monitoring of the evolution of local natural capital value from the "as is" situation to the "to be" situation, derived by interventions that affect both the sphere of redevelopment and new intervention planning that can be adopted locally. Moreover, this model implies a new approach to decision making through the complete integration of NBSs within local authorities' programming, management, and control processes. Such programming and control processes, on the one hand, allow the identification of which NBSs should be adopted and the impact they can create at the eco-systemic level (also using specific indicators and other measurement instruments). On the other hand, they allow the identification of implications, in terms of resilience, produced by an investment in NBSs over social and economic components at a local level and the types of benefits that can be obtained.

\section{Conclusions}

With the rise of the urbanocene and in a pandemic scenario amplified by large-scale globalization processes, NBSs invite us to recover thinking from ancient Greece, where the Earth had two names: ge (or Gaia, the Earth from the surface up, looking at the sky) and chton (the underworld's outer face), which corresponds to two distinct but interdependent and inseparable realities. NBSs call for a deeper relationship among human beings, ge, and chton. A relationship based on an intertwined resilient over time and across space is desirable.

This research analyzed whether such resilience could be affirmed at a local level by studying whether the application of NBSs in medium-sized cities can promote sustainability in those cities. The abovementioned concept of resilience has been connected with urban sustainability through the framework of the 2030 Agenda and the SDGs. Policy makers, local communities, and society must seriously consider the means by which to foster the resilience of smaller, more manageable contexts that contribute to Earth's system resilience [15]: NBSs are pivotal levers to undertake those means.

From this perspective, the Italian case studies discussed herein deal with relevant NBS urban projects and constitute eloquent sources of lessons learned and best practices for knowledge sharing and foster awareness about the increasing need for sustainable urban management and its related tools for the promotion of sustainable cities.

Eventually, we can draw some relevant findings and comments:

i. NBSs help give value to the local dimension of sustainability, and through actions related to specific aspects (specified resilience), advantages can be obtained that generate well-being and the health of the local population (the estimation of reduction of $\mathrm{CO}_{2}$ in the case of Lucca and the outdoor services and activities regarding social care, inclusive jobs, training, education, sports, creativity, and entertainment, in the case of Latina, are examples).

ii. NBSs represent levers on which enlarged governance can be consolidated through the active participation of a series of subjects. Multiple proposals and opportunities can be developed including direct implications for local businesses (in both cases the engagement of representatives of civil society, local government and, in Latina, also businesses emerge as relevant). 
iii. The systemic logic that guides the approach to interpreting resilience also has implications on the management/managerial level. This is relevant because it promotes the real integration of NBSs in local natural heritage management processes (again, in both cases, the perception of the close relationship existing between NBSs and urban resilience moves towards active managerial and governance initiatives promoted by local authorities, with the crucial involvement of local relevant stakeholders).

iv. Thus, NBSs contribute to the logic of management and decision making. The proposed framework of variables listed above allows monitoring in the key of "as is" $\rightarrow$ "to be" of the evolution of the value of the local natural capital (a process that, in our cases, is outlined in the improvement of the level of resilience capacity described for both cities in Figure 2a,b).

v. Concerning the state of the art, the empirical evidence we obtained in this study confirms, for both cases, the close interaction among different types of NBSs and the mutual interaction/valuation among them.

However, it should be pointed out that our research dealt with two NBS projects that are still in progress for which long-term outcomes and feedback are not yet available. The future development of the projects (and the related results that will be reached) will also allow for the creation of a closer connection between the results obtained in terms of the improvement of local conditions, the level of resilience capacity that emerges, and the measurement of the contribution of these projects to SDGs. This connection will provide an opportunity to demonstrate (through quantitative data) the impact of investment of NBSs on the Agenda 2030: The definition of a measurement model from this perspective represents one of the most relevant lines of future research.

Author Contributions: Conceptualization, M.E.C., M.B. and C.S.; Funding acquisition, M.E.C. and M.C.; Investigation, M.E.C., M.B., M.C. and C.S.; Methodology, M.B. and C.S.; Resources, M.E.C., M.B., M.C. and C.S.; Supervision, M.E.C., M.B., M.C. and C.S.; Visualization, M.E.C.; Writingoriginal draft, M.E.C., M.B. and C.S.; Writing—review and editing, M.E.C., M.B., M.C. and C.S. All authors have read and agreed to the published version of the manuscript.

Funding: This work was financed by Sapienza University of Rome projects 2018 (Principal Investigator Prof. M.E. Conti), prot. RG11816432851FA6 and 2020, prot. RM120172A913C58B (Principal Investigator Prof. M. Calabrese).

Institutional Review Board Statement: The present study was conducted according to the University Sapienza of Rome Ethical Code-Rectoral Decree n. 1636, n. 0032773, 23 May 2012.

Informed Consent Statement: Informed consent was obtained from all subjects involved in the study.

Data Availability Statement: Data available upon request.

Conflicts of Interest: The authors declare that they have no known competing financial interest or personal relationships that could have appeared to influence the work reported in this paper.

\section{References}

1. Crutzen, P.J. The "anthropocene". In Earth System Science in the Anthropocene; Ehlers, E., Krafft, T., Eds.; Springer: Berlin/Heidelberg, Germany, 2006; pp. 13-18.

2. West, G.B. Scale: The Universal Laws of Growth, Innovation, Sustainability, and the Pace of Life in Organisms, Cities, Economies, and Companies; Penguin Books: London, UK, 2017.

3. Glaeser, E. Il Trionfo Della Città: Come la Nostra Più Grande Invenzione ci ha Reso Più Ricchi, Intelligenti, Ecologici, Sani e Felici; Giunti Editore: Florence, Italy, 2013.

4. Faivre, N.; Fritz, M.; Freitas, T.; de Boissezon, B.; Vandewoestijne, S. Nature-based solutions in the EU: Innovating with nature to address social, economic and environmental challenges. Environ. Res. 2017, 159, 509-518. [CrossRef]

5. MacKinnon, K.; Sobrevila, C.; Hickey, V. Biodiversity, Climate Change, and Adaptation: Nature-Based Solutions from the World Bank Portfolio, No. 46726; The World Bank: Washington, DC, USA, 2008.

6. Cohen-Shacham, E.; Walters, G.; Janzen, C.; Maginnis, S. Nature-Based Solutions to Address Global Societal Challenges; IUCN: Gland, Switzerland, 2016. 
7. European Commission. Towards an EU Research and Innovation Policy Agenda for Nature-Based Solutions E Re-Naturing Cities. Final Report of the Horizon 2020 Expert Group on 'Nature-Based Solutions and Re-Naturing Cities; European Commission: Brussels, Belgium, 2020.

8. Steffen, W.; Richardson, K.; Rockström, J.; Cornell, S.E.; Fetzer, I.; Bennett, E.M.; Biggs, R.; Carpenter, S.R.; de Vries, W.; de Wit, C.A.; et al. Planetary boundaries: Guiding human development on a changing planet. Science 2015, 347, 1259855. [CrossRef] [PubMed]

9. Van den Bosch, M.; Ode Sang, Å. Urban natural environments as nature-based solutions for improved public health—A systematic review of reviews. Environ. Res. 2017, 158, 373-384. [CrossRef]

10. Crane, M.; Lloyd, S.; Haines, A.; Ding, D.; Hutchinson, E.; Belesova, K.; Davies, M.; Osrin, D.; Zimmermann, N.; Capon, A.; et al. Transforming cities for sustainability: A health perspective. Environ. Int. 2021, 147, 106366. [CrossRef] [PubMed]

11. United Nations. World Urbanisation Prospects: The 2017 Revision; United Nations: New York, NY, USA, 2018.

12. Berkes, F.; Colding, J.; Folke, C. Navigating Social-Ecological Systems: Building Resilience for Complexity and Change; Cambridge University Press: Cambridge, MA, USA, 2008.

13. Walker, B.; Holling, C.S.; Carpenter, S.R.; Kinzig, A. Resilience, adaptability and transformability in social-ecological systems. Ecol. Soc. 2004, 9, 5. [CrossRef]

14. Walker, B.H.; Abel, N.; Anderies, J.M.; Ryan, P. Resilience, adaptability, and transformability in the Goulburn-Broken Catchment, Australia. Ecol. Soc. 2009, 14, 12. [CrossRef]

15. Folke, C.; Carpenter, S.R.; Walker, B.; Scheffer, M.; Chapin, T.; Rockström, J. Resilience thinking: Integrating resilience, adaptability and transformability. Ecol. Soc. 2010, 15, 20. [CrossRef]

16. Folke, C.; Biggs, R.; Norström, A.V.; Reyers, B.; Rockström, J. Social-ecological resilience and biosphere-based sustainability science. Ecol. Soc. 2016, 21, 41. [CrossRef]

17. Manca, A.R.; Benczur, P.; Giovannini, E. Building a Scientific Narrative towards a More Resilient EU Society. Part 1: A Conceptual Framework, No. JRC106265; Joint Research Centre (Seville Site): Ispra, Italy, 2017.

18. Giovannini, E.; Benczur, P.; Campolongo, F.; Cariboni, J.; Manca, A.R. Time for Transformative Resilience: The COVID-19 Emergency (No. JRC120489); Joint Research Centre: Ispra, Italy, 2020.

19. Simone, C.; Iandolo, F.; Fulco, I.; Loia, F. Rome was not built in a day. Resilience and the eternal city: Insights for urban management. Cities 2021, 110, 103070. [CrossRef]

20. Gordon, J.E. Structures: Or Why Things Don't Fall Down; Plenum Press: New York, NY, USA, 1978.

21. Sharifi, A.; Yamagata, Y. Principles and criteria for assessing urban energy resilience: A literature review. Renew. Sustain. Energy Rev. 2016, 60, 1654-1677. [CrossRef]

22. Holling, C.S. Resilience and stability of ecological systems. Annu. Rev. Ecol. Syst. 1973, 4, 1-23. [CrossRef]

23. Klein, R.J.T.; Nicholls, R.J.; Thomalla, F. Resilience to natural hazards: How useful is this concept? Glob. Environ. Chang. B Environ. Hazards 2003, 5, 35-45. [CrossRef]

24. Kobasa, S.C.; Maddi, S.R.; Kahn, S. Hardiness and health: A prospective study. J. Pers. Soc. Psychol. 1982, 42, 168-177. [CrossRef] [PubMed]

25. Adger, W.N. Social and ecological resilience: Are they related? Prog. Hum. Geogr. 2000, 24, 347-364. [CrossRef]

26. Riolli, L.; Savicki, V.; Cepani, A. Resilience in the face of catastrophe: Optimism, personality and coping in the Kosovo crisis. J. Appl. Soc. Psychol. 2002, 32, 1604-1627. [CrossRef]

27. Wiley, N. The micro-macro problem in social theory. Sociol. Theory 1988, 6, 254-261. [CrossRef]

28. Adger, W.N.; Hughes, T.P.; Folke, C.; Carpenter, S.R.; Rockström, J. Social-ecological resilience to coastal disasters. Science 2005, 309, 1036-1039. [CrossRef]

29. Nyström, M.; Jouffray, J.B.; Norström, A.V.; Crona, B.; Søgaard Jørgensen, P.; Carpenter, S.R.; Bodin, Ö.; Galaz, V.; Folke, C. Anatomy and resilience of the global production ecosystem. Nature 2019, 575, 98-108. [CrossRef]

30. Coutu, D.L. How resilience works. Harv. Bus. Rev. 2002, 80, 46-56.

31. Vale, L.J. The politics of resilient cities: Whose resilience and whose city? Build. Res. Inf. 2014, 42, 191-201. [CrossRef]

32. Fitzgibbons, J.; Mitchell, C.L. Just urban futures? Exploring equity in “100 Resilient Cities". World Dev. 2019, 122, 648-659. [CrossRef]

33. Meerow, S.; Newell, J.P. Urban resilience for whom, what, when, where, and why? Urban Geogr. 2019, 40, 309-329. [CrossRef]

34. Batty, M. Cities and Complexity: Understanding Cities with Cellular Automata, Agent-Based Models, and Fractals; The MIT Press: Cambridge, MA, USA, 2007.

35. Barile, S.; Simone, C.; La Sala, A.; Conti, M.E. Surfing the complex interaction between new technology and norms: A resistance or resilience issue? Insights by the Viable System Approach (VSA). Acta Eur. Syst. 2019, 9, 93-104. [CrossRef]

36. Béné, C.; Mehta, L.; McGranahan, G.; Cannon, T.; Gupte, J.; Tanner, T. Resilience as a policy narrative: Potentials and limits in the context of urban planning. Clim. Dev. 2018, 10, 116-133. [CrossRef]

37. Davoudi, S.; Porter, L. The politics of resilience for planning: A cautionary note. Plan. Theory Pract. 2012, 13, 329-333. [CrossRef]

38. Fainstein, S. Resilience and justice. Int. J. Urban Reg. Res. 2015, 39, 157-167. [CrossRef]

39. Friend, R.; Moench, M. What is the purpose of urban climate resilience? Implications for addressing poverty and vulnerability. Urban Clim. 2013, 6, 98-113. [CrossRef] 
40. Gillard, R. Questioning the diffusion of resilience discourses in pursuit of transformational change. Glob. Environ. Politics 2016, 16, 13-20. [CrossRef]

41. Kaika, M. 'Don't call me resilient again!': The New Urban Agenda as immunology ... or ... what happens when communities refuse to be vaccinated with 'smart cities' and indicators. Environ. Urban. 2017, 29, 89-102. [CrossRef]

42. Oteng-Ababio, M.; Sarfo, K.O.; Owusu-Sekyere, E. Exploring the realities of resilience: Case study of Kantamanto Market fire in Accra, Ghana. Int. J. Disaster Risk Reduct. 2015, 12, 311-318. [CrossRef]

43. Ziervogel, G.; Pelling, M.; Cartwright, A.; Chu, E.; Deshpande, T.; Harris, L.; Hyams, K.; Kaunda, J.; Klaus, B.; Michael, K.; et al. Inserting rights and justice into urban resilience: A focus on everyday risk. Environ. Urban. 2017, 29, 123-138. [CrossRef]

44. Cifdaloz, O.; Regmi, A.; Anderies, J.M.; Rodriguez, A.A. Robustness, vulnerability, and adaptive capacity in small-scale socialecological systems: The Pumpa irrigation system in Nepal. Ecol. Soc. 2010, 15, 39-70. [CrossRef]

45. Koirala, S. SMEs: Key Drivers of Green and Inclusive Growth; OECD: Paris, France, 2019.

46. Secretariat of the Convention on Biological Diversity. The Ecosystem Approach; Secretariat of the Convention on Biological Diversity: Montreal, QC, Canada, 2004.

47. Abson, D.J.; von Wehrden, H.; Baumgärtner, S.; Fischer, J.; Hanspach, J.; Härdtle, W.; Heinrichs, H.; Klein, A.M.; Lang, D.J.; Martens, P.; et al. Ecosystem services as a boundary object for sustainability. Ecol. Econ. 2014, 103, 29-37. [CrossRef]

48. Conti, M.E. Il Management Ambientale: Teorie, Metodi e Strumenti in una Prospettiva Sostenibile; Edizioni Nuova Cultura: Roma, Italy, 2018.

49. Ciasullo, R.; Simone, C.; Conti, M.E. The complex issues of carbon sink: A critical overview. Int. J. Environ. Health 2014, 7, 171-195. [CrossRef]

50. Balian, E.; Eggermont, H.; Le Roux, X. Outcomes of the Strategic Foresight Workshop “Nature-Based Solutions in a BiodivERsA context", Brussels, 11-12 June 2014. BiodivERsA Report. Available online: http://www.biodiversa.org/671 (accessed on 31 January 2015).

51. Waylen, K.A.; Hastings, E.J.; Banks, E.A.; Holstead, K.L.; Irvine, R.J.; Blackstock, K.L. The need to disentangle key concepts from ecosystem-approach jargon. Conserv. Biol. 2014, 28, 1215-1224. [CrossRef] [PubMed]

52. Maes, J.; Jacobs, S. Nature-based solutions for europe's sustainable development. Conserv. Lett. 2017, 10, 121-124. [CrossRef]

53. Raymond, C.M.; Breil, M.; Nita, M.R.; Kabisch, N.; de Bel, M.; Enzi, V.; Frantzeskaki, N.; Geneletti, G.; Lovinger, L.; Cardinaletti, M.; et al. An Impact Evaluation Framework to Support Planning and Evaluation of Nature-Based Solutions Projects. Report prepared by the EKLIPSE Expert Working Group on Nature-Based Solutions to Promote Climate Resilience in Urban Areas; Centre for Ecology and Hydrology: Bailrigg, England, 2017.

54. Raymond, C.M.; Frantzeskaki, N.; Kabisch, N.; Berry, P.; Breil, M.; Nita, M.R.; Geneletti, D.; Calfapietra, C. A framework for assessing and implementing the co-benefits of nature-based solutions in urban areas. Environ. Sci. Policy 2017, 77, 15-24. [CrossRef]

55. Kabisch, N.; Stadler, J.; Korn, H.; Bonn, A. Nature-based solutions for societal goals under climate change in urban areassynthesis and ways forward. In Nature-Based Solutions to Climate Change Adaptation in Urban Areas: Linkages between Science, Policy and Practice; Kabisch, N., Korn, H., Stadler, J., Bonn, A., Eds.; Springer International Publishing: Cham, Switzerland, 2017; pp. 323-336.

56. Keesstra, S.; Nunes, J.; Novara, A.; Finger, D.; Avelar, D.; Kalantari, Z.; Cerdà, A. The superior effect of nature based solutions in land management for enhancing ecosystem services. Sci. Total Environ. 2018, 610-611, 997-1009. [CrossRef]

57. Depietri, Y.; McPhearson, T. Integrating the grey, green, and blue in cities: Nature-based solutions for climate change adaptation and risk reduction. In Nature-Based Solutions to Climate Change Adaptation in Urban Areas: Linkages between Science, Policy and Practice; Kabisch, N., Korn, H., Stadler, J., Bonn, A., Eds.; Springer International Publishing: Cham, Switzerland, 2017 ; pp. 91-109.

58. USEPA. Performance of Green Infrastructure. Available online: https://www.epa.gov/green-infrastructure/performance-greeninfrastructure (accessed on 12 May 2021).

59. Benedict, M.A.; McMahon, E.T. Green infrastructure: Smart conservation for the 21st century. Renew. Resour. J. 2002, $20,12-17$.

60. Benedict, M.A.; McMahon, E.T. Green Infrastructure: Linking Landscapes and Communities; Island Press: Washington, DC, USA, 2006.

61. Tyrväinen, L.; Pauleit, S.; Seeland, K.; de Vries, S. Benefits and uses of urban forests and trees. In Urban Forests and Trees, Konijnendijk; Konijnendijk, C.C., Nilsson, K., Randrup, T.B., Schipperijn, J., Eds.; Springer: Berlin, Germany, $2005 ;$ pp. 81-114.

62. Childers, D.L.; Bois, P.; Hartnett, H.E.; McPhearson, T.; Metson, G.S.; Sanchez, C.A. Urban ecological infrastructure: An inclusive concept for the non-built urban environment. Elem. Sci. Anthr. 2019, 7, 46. [CrossRef]

63. Odum, H.T.; Odum, B. Concepts and methods of ecological engineering. Ecol. Eng. 2003, 20, 339-361. [CrossRef]

64. Kangas, P. Ecological Engineering: Principles and Practice; CRC Press: Boca Raton, FL, USA, 2003.

65. Cheong, S.-M.; Silliman, B.; Wong, P.P.; van Wesenbeeck, B.; Kim, C.-K.; Guannel, G. Coastal adaptation with ecological engineering. Nat. Clim. Chang. 2013, 3, 787-791. [CrossRef]

66. Duraiappah, A.K.; Naeem, S.; Agardy, T.; Ash, N.J.; Cooper, H.D.; Diaz, S.; Faith, D.P.; Mace, G.; McNeely, J.A.; Mooney, H.A.; et al. Ecosystems and Human Well-Being: Biodiversity Synthesis; A Report of the Millennium Ecosystem Assessment; World Resources Institute: Washington, DC, USA, 2005.

67. Mueller, N.; Rojas-Rueda, D.; Khreis, H.; Cirach, M.; Andrés, D.; Ballester, J.; Bartoll, X.; Daher, C.; Deluca, A.; Echave, C.; et al. Changing the urban design of cities for health: The superblock model. Environ. Int. 2020, 134, 105132. [CrossRef] 
68. Pauleit, S.; Zölch, T.; Hansen, R.; Randrup, T.B.; Konijnendijk van den Bosch, C. Nature-based solutions and climate change-four shades of green. In Nature-Based Solutions to Climate Change Adaptation in Urban Areas: Linkages between Science, Policy and Practice; Kabisch, N., Korn, H., Stadler, J., Bonn, A., Eds.; Springer International Publishing: Cham, Switzerland, 2017 ; pp. $29-49$.

69. Gómez-Baggethun, E.; de Groot, R.; Lomas, P.L.; Montes, C. The history of ecosystem services in economic theory and practice: From early notions to markets and payment schemes. Ecol. Econ. 2010, 69, 1209-1218. [CrossRef]

70. Gómez-Baggethun, E.; Gren, Å.; Barton, D.N.; Langemeyer, J.; McPhearson, T.; O’Farrell, P.; Andersson, E.; Hamstead, Z.; Kremer, P. Urban ecosystem services. In Urbanization, Biodiversity and Ecosystem Services: Challenges and Opportunities: A Global Assessment; Elmqvist, T., Fragkias, M., Goodness, J., Güneralp, B., Marcotullio, P.J., McDonald, R.I., Parnell, S., Schewenius, M., Sendstad, M., Seto, K.C., et al., Eds.; Springer: Dordrecht, The Netherlands, 2013; pp. 175-251.

71. Secretariat of the Convention on Biological Diversity. Connecting Biodiversity and Climate Change Mitigation and Adaptation: Report of the Second Ad Hoc Technical Expert Group on Biodiversity and Climate Change, Technical Series No. 41; Secretariat of the Convention on Biological Diversity: Montreal, QC, Canada, 2009.

72. Tonne, C.; Adair, L.; Adlakha, D.; Anguelovski, I.; Belesova, K.; Berger, M.; Brelsford, C.; Dadvand, P.; Dimitrova, A.; Giles-Corti, B.; et al. Defining pathways to healthy sustainable urban development. Environ. Int. 2021, 146, 106236. [CrossRef] [PubMed]

73. La Notte, A.; D’Amato, D.; Mäkinen, H.; Paracchini, M.L.; Liquete, C.; Egoh, B.; Geneletti, D.; Crossman, N.D. Ecosystem services classification: A systems ecology perspective of the cascade framework. Ecol. Indic. 2017, 74, 392-402. [CrossRef]

74. Escobedo, F.J.; Giannico, V.; Jim, C.Y.; Sanesi, G.; Lafortezza, R. Urban forests, ecosystem services, green infrastructure and nature-based solutions: Nexus or evolving metaphors? Urban For. Urban Green. 2019, 37, 3-12. [CrossRef]

75. Almenar, J.B.; Elliot, T.; Rugani, B.; Philippe, B.; Navarrete Gutierrez, T.; Sonnemann, G.; Geneletti, D. Nexus between nature-based solutions, ecosystem services and urban challenges. Land Use Policy 2021, 100, 104898. [CrossRef]

76. Eggermont, H.; Balian, E.; Azevedo, M.; Beumer, V.; Brodin, T.; Claudet, J.; Fady, B.; Grube, M.; Keune, H.; Lamarque, P.; et al. Nature-based solutions: New influence for environmental management and research in Europe. GAIA-Ecol. Perspect. Sci. Soc. 2015, 24, 243-248. [CrossRef]

77. Rittel, H.W.J.; Webber, M.M. Dilemmas in a general theory of planning. Policy Sci. 1973, 4, 155-169. [CrossRef]

78. Costanza, R.; Folke, C. Valuing ecosystem services with efficiency, fairness and sustainability as goals. In Nature's Services: Societal Dependence on Natural Ecosystems; Daily, G.C., Ed.; Island Press: Washington, DC, USA, 1997; pp. 49-70.

79. Hartig, T.; Mitchell, R.; de Vries, S.; Frumkin, H. Nature and health. Annu. Rev. Public Health 2014, 35, 207-228. [CrossRef] [PubMed]

80. Coutts, C.; Hahn, M. Green infrastructure, ecosystem services, and human health. Int. J. Environ. Res. Public Health 2015, 12, 9768-9798. [CrossRef]

81. Hunter, R.F.; Cleland, C.; Cleary, A.; Droomers, M.; Wheeler, B.W.; Sinnett, D.; Nieuwenhuijsen, M.J.; Braubach, M. Environmental, health, wellbeing, social and equity effects of urban green space interventions: A meta-narrative evidence synthesis. Environ. Int. 2019, 130, 104923. [CrossRef]

82. Lachowycz, K.; Jones, A.P. Does walking explain associations between access to greenspace and lower mortality? Soc. Sci. Med. 2014, 107, 9-17. [CrossRef]

83. Thompson Coon, J.; Boddy, K.; Stein, K.; Whear, R.; Barton, J.; Depledge, M.H. Does participating in physical activity in outdoor natural environments have a greater effect on physical and mental wellbeing than physical activity indoors? A systematic review. Environ. Sci. Technol. 2011, 45, 1761-1772. [CrossRef]

84. WHO. Urban Green Spaces and Health; WHO Regional Office for Europe: Copenhagen, Denmark, 2016.

85. Bird, W. Natural Thinking; Royal Society for the Protection of Birds: Sandy, UK, 2007.

86. Van den Berg, A.E.; Maas, J.; Verheij, R.A.; Groenewegen, P.P. Green space as a buffer between stressful life events and health. Soc. Sci. Med. 2010, 70, 1203-1210. [CrossRef] [PubMed]

87. Duncan, S.; Barrett, L.F. Affect is a form of cognition: A neurobiological analysis. Cogn. Emot. 2007, 21, 1184-1211. [CrossRef]

88. Conti, M.E. From animal instinct to human birth theory: An entangled path. Int. J. Environ. Health 2019, 9, 343-371. [CrossRef]

89. Kelly, V.C. A primer of affect psychology. In The Art of Intimacy and the Hidden Challenge of Shame; Kelly, V.C., Ed.; Tomkins Press: Raleigh, NC, USA, 2009; pp. 158-191.

90. Kelly, V.C. The Art of Intimacy and the Hidden Challenge of Shame; Maine Authors Publishing: Thomaston, ME, USA, 2012.

91. Malone, K.; Tranter, P. Children's Environments: A Study of Children's Environmental Cognitive Development in Relation to their Schoolground Experiences, ARC Project Report; Monash University: Melbourne, Australia, 2003.

92. Li, Q.; Morimoto, K.; Kobayashi, M.; Inagaki, H.; Katsumata, M.; Hirata, Y.; Hirata, K.; Suzuki, H.; Li, Y.J.; Wakayama, Y.; et al. Visiting a forest, but not a city, increases human natural killer activity and expression of anti-cancer proteins. Int. J. Immunopathol. Pharmacol. 2008, 21, 117-127. [CrossRef]

93. Lovasi, G.S.; Quinn, J.W.; Neckerman, K.M.; Perzanowski, M.S.; Rundle, A. Children living in areas with more street trees have lower prevalence of asthma. J. Epidemiol. Community Health 2008, 62, 647-649. [CrossRef] [PubMed]

94. Rook, G.A. Regulation of the immune system by biodiversity from the natural environment: An ecosystem service essential to health. Proc. Natl. Acad. Sci. USA 2013, 110, 18360-18367. [CrossRef] [PubMed] 
95. Ruokolainen, L.; von Hertzen, L.; Fyhrquist, N.; Laatikainen, T.; Lehtomäki, J.; Auvinen, P.; Karvonen, A.M.; Hyvärinen, A.; Tillmann, V.; Niemelä, O.; et al. Green areas around homes reduce atopic sensitization in children. Allergy 2015, 70, 195-202. [CrossRef]

96. Hanski, I.; von Hertzen, L.; Fyhrquist, N.; Koskinen, K.; Torppa, K.; Laatikainen, T.; Karisola, P.; Auvinen, P.; Paulin, L.; Mäkelä, M.J.; et al. Environmental biodiversity, human microbiota, and allergy are interrelated. Proc. Natl. Acad. Sci. USA 2012, 109, 8334-8339. [CrossRef] [PubMed]

97. Seeland, K.; Dübendorfer, S.; Hansmann, R. Making friends in Zurich's urban forests and parks: The role of public green space for social inclusion of youths from different cultures. For. Policy Econ. 2009, 11, 10-17. [CrossRef]

98. Shanahan, D.F.; Lin, B.B.; Bush, R.; Gaston, K.J.; Dean, J.H.; Barber, E.; Fuller, R.A. Toward improved public health outcomes from urban nature. Am. J. Public Health 2015, 105, 470-477. [CrossRef]

99. Thompson, C.W.; Aspinall, P.; Roe, J.; Robertson, L.; Miller, D. Mitigating stress and supporting health in deprived urban communities: The importance of green space and the social environment. Int. J. Environ. Res. Public Health 2016, 13, 440. [CrossRef] [PubMed]

100. Schwarte, C.; Adebowale, M. Environmental Justice and Race Equality in the European Union; Capacity Global: London, UK, 2007; ISBN 139780954725563.

101. Kabisch, N.; Haase, D. Green justice or just green? Provision of urban green spaces in Berlin, Germany. Landsc. Urban Plan. 2014, 122, 129-139. [CrossRef]

102. Xing, Y.; Jones, P.; Donnison, I. Characterisation of nature-based solutions for the built environment. Sustainability 2017, 9 , 149. [CrossRef]

103. Kabisch, N.; van den Bosch, M.; Lafortezza, R. The health benefits of nature-based solutions to urbanization challenges for children and the elderly-A systematic review. Environ. Res. 2017, 159, 362-373. [CrossRef]

104. Allen, J.; Balfour, R. Natural Solutions for Tackling Health Inequalities; UCL Institute of Health Equity: London, UK, 2014.

105. Xu, Y.; Dadvand, P.; Barrera-Gómez, J.; Sartini, C.; Marí-Dell'Olmo, M.; Borrell, C.; Medina-Ramón, M.; Sunyer, J.; Basagaña, $X$. Differences on the effect of heat waves on mortality by sociodemographic and urban landscape characteristics. J. Epidemiol. Community Health 2013, 67, 519-525. [CrossRef]

106. Xu, Z.; FitzGerald, G.; Guo, Y.; Jalaludin, B.; Tong, S. Impact of heatwave on mortality under different heatwave definitions: A systematic review and meta-analysis. Environ. Int. 2016, 89-90, 193-203. [CrossRef]

107. Landrigan, P.J.; Fuller, R.; Acosta, N.J.R.; Adeyi, O.; Arnold, R.; Basu, N.N.; Baldé, A.B.; Bertollini, R.; Bose-O’Reilly, S.; Boufford, J.I.; et al. The Lancet Commission on pollution and health. Lancet 2018, 391, 462-512. [CrossRef]

108. Giacomello, E. CTBUH Research Seed Funding Project 2013-Green Living Façade for Tall Buildings: Bosco Verticale. In Proceedings of the CTBUH 2014 Conference, Shanghai, China, 16-19 September 2014; pp. 104-111.

109. Giacomello, E. Bosco Verticale, Milan: A new urban forest rises in Milan. CTBUH J. 2015, 1, 12-18.

110. Giacomello, E.; Valagussa, M. Vertical Greenery: Evaluating the High-Rise Vegetation of the Bosco Verticale, Milan; Council on Tall Buildings and Urban Habitat: Chicago, IL, USA, 2015.

111. Edmondson, A.C.; McManus, S.E. Methodological fit in management field research. Acad. Manag. Rev. 2007, 32, 1246-1264. [CrossRef]

112. Yin, R.K. Qualitative Research from Start to Finish; Guildford Press: New York, NY, USA, 2016.

113. Glaser, B.G. The constant comparative method of qualitative analysis. Soc. Probl. 1965, 12, 436-445. [CrossRef]

114. Glaser, B.G.; Strauss, A.L. Discovery of Grounded Theory: Strategies for Qualitative Research; Routledge: England, UK, 1967.

115. Taylor, S.J.; Bogdan, R.; DeVault, M. Introduction to Qualitative Research Methods: A Guidebook and Resource; John Wiley \& Sons: Hoboken, NJ, USA, 2015.

116. Hagedorn, G.; Kalmus, P.; Mann, M.; Vicca, S.; Van den Berge, J.; van Ypersele, J.P.; Hayhoe, K. International letter. Science 2019, 364, 139-140. [CrossRef]

117. Warren, M. Thousands of scientists are backing the kids striking for climate change. Nature 2019, 567, 291-292. [CrossRef]

118. Annesi, N.; Battaglia, M.; Gragnani, P.; Iraldo, F. Integrating the 2030 Agenda at the municipal level: Multilevel pressures and institutional shift. Land Use Policy 2021, 105, 105424. [CrossRef]

119. WRI; WBCSD. Technical Guidance for Calculating Emissions. Supplement to the Corporate Value Chain (Scope 3). Accounting E Reporting Standard; World Resources Institute: Washington, DC, USA, 2013.

120. Nikolaidou, S.; Klöti, T.; Tappert, S.; Drilling, M. Urban gardening and green space governance: Towards new collaborative planning practices. Urban Plan. 2016, 1, 5-19. [CrossRef]

121. Tornaghi, C.; Certomà, C. Urban Gardening as Politics; Routledge: England, UK, 2018.

122. Horst, M.; McClintock, N.; Hoey, L. The intersection of planning, urban agriculture, and food justice: A review of the literature. J. Am. Plan. Assoc. 2017, 83, 277-295. [CrossRef]

123. Certomà, C.; Martellozzo, F. Cultivating urban justice? A spatial exploration of urban gardening crossing spatial and environmental injustice conditions. Appl. Geogr. 2019, 106, 60-70. [CrossRef]

124. Schram-Bijkerk, D.; Otte, P.; Dirven, L.; Breure, A.M. Indicators to support healthy urban gardening in urban management. Sci. Total Environ. 2018, 621, 863-871. [CrossRef] [PubMed] 